\title{
ДИНАМІКА ЗМІН ПРОЦЕСІВ ЛІПОПЕРОКСИДАЦІї ТА АНТИОКСИДАНТНОЇ СИСТЕМИ В ЛЕГЕНЯХ У ПАТОГЕНЕЗІ РОЗВИТКУ ЕКСПЕРИМЕНТАЛЬНОГО КОНТАКТНОГО ДЕРМАТИТУ
}

\section{Львівський медичний інститут}

ФМ. М. Регеда-Фурдичко

PЕЗЮМЕ. Метою нашого дослідження стало з' ясування особливостей стану прооксидантноїі антиоксидантної систем у легенях морських свинок у динаміці розвитку контактного дерматиту.

Матеріал і методи. Експериментальні дослідження проводили на морських свинках, поділених на 5 груп по 9 тварин у кожній. До І групи (контроль) відносили інтактних морських свинок, до ІІ - тварин з експериментальним контактним дерматитом (4 доба), до III - морські свинки на 8 добу модельного процесу, до IV - тварини на 10 добу, до V - тварини на 18 добу контактного дерматиту. Для детального аналізу та інтерпретації показників прооксидантної та антиоксидантної систем у різні доби експерименту умовно виділяли два періоди розвитку експериментального контактного дерматиту: ранній і пізній. Ранній період включав групу тварин на 4 та 8 доби експерименту, пізній - на 10 та 18 доби контактного дерматиту.

Експериментальну модель контактного дерматиту відтворювали на морських свинках за методом В. А. Волковой (2010). Стан вільнорадикального окиснення ліпідів у легенях визначали за вмістом дієнових кон'югатів за методом В. Г. Гаврилова, М. І. Мишкорудної (1989), малонового діальдегіду - за методом Е. Н. Коробейникова (1989). Ступінь активності антиоксидантної системи оцінювали за вмістом ферментів - супероксиддисмутази за методом R. Fried (1975), каталази за методом R. Holmes, C. Masters (1970), глутатіонпероксидази - за методом О. Г. Архиповой (1988) та глутатіонредуктази - за методом В. М. Моїна (1986).

Результати. У роботі встановлено поступове інтенсивне зростання продуктів перекисного окиснення ліпідів - дієнових кон'югатів та малонового діальдегіду, особливо виражене на 18 добу експерименту. Виявлено зниження активності супероксиддисмутази, каталази, глутатіонредуктази та глутатіонпероксидази в легенях морських свинок у пізньому періоді експериментального контактного дерматиту. Отримані результати свідчать про порушення балансу прооксидантної та антиоксидантної систем, яке проявляється посиленням синтезу вільних радикалів на тлі пригнічення компенсаторних реакцій.

КЛючОВІ СЛОВА: контактний дерматит; малоновий діальдегід; дієнові кон'югати; супероксиддисмутаза; каталаза; глутатіонпероксидаза; глутатіонредуктаза.

Вступ. Попри те, що в останні десятиліття проблема лікування захворювань шкіри неодноразово ставала предметом наукових пошуків вітчизняних та зарубіжних науковців, це питання й досі не втратило своєї наукової значимості та актуальності $[9,11]$. Жодна з існуючих на сьогодні концепцій патогенезу контактного дерматиту (КД) не $\epsilon$ універсальною і не розкриває всіх патогенетичних особливостей, що обумовлює необхідність проведення подальших досліджень у вказаному напрямку [10].

Перекисне окиснення ліпідів (ПОЛ) $є$ одним із найважливіших окиснювальних процесів в організмі людини. На сьогодні існує багато досліджень, які свідчать, що виникнення та розвиток різноманітних патологій супроводжуються активацією вільнорадикальних реакцій $[4,8]$. Основним ініціатором вільнорадикального окиснення $\epsilon$ активні форми кисню, які можуть зростати під дією несприятливих факторів і спричиняти оксидативний стрес [8].

Процеси перекисного окиснення ліпідів розглядають як один із важливих механізмів клітинної патології, що лежить в основі багатьох негатив- них ефектів. Продукти ПОЛ спроможні викликати безпосереднє пошкодження легеневої тканини, оскільки легені $\epsilon$ найбільшою біологічною мембраною організму, поверхня якої постійно контактує з активними ініціаторами перекисного окиснення $[7,12,15,16]$.

Дисбаланс у рівновазі між процесами пол і антиоксидантною системою (АОС), що виникає в разі гіперпродукції вільних радикалів або падіння рівня тканинних антиоксидантів, зумовлює лавоподібну реакцію переокиснення, яка призводить до загибелі клітин [10, 12].

Значення порушень рівноваги в системі ПОЛАОС обґрунтовують необхідність і актуальність вивчення їх ролі в патогенезі контактних дерматитів, тому метою нашого дослідження стало з'ясування особливостей стану прооксидантної і антиоксидантної систем у легенях морських свинок у динаміці розвитку контактного дерматиту.

Матеріал і методи дослідження. Експериментальні дослідження проводили на 51 морській свинці (самці) масою 180-220 г, поділених на 5 груп по 9 тварин у кожній, крім першої (15 тварин). До І групи (контроль) відносили інтактних 
Огляди літератури, оригінальні дослідження, погляд на проблему, випадок з практики, короткі повідомлення морських свинок, до II, III, IV i V - тварин з експериментальним КД відповідно на 4 8, 10 і 18 доби. Для детального аналізу та інтерпретації показників оксидантної та антиоксидантної систем у різні доби експерименту виділяли умовно два періоди розвитку експериментального КД: ранній і пізній. Ранній період включав групу тварин із КД на 4 та 8 доби експерименту. Пізній - морські свинки на 10 та 18 доби КД. Вибрані доби КД були обумовлені класичними стадіями розвитку запального процесу.

Експериментальну модель КД відтворювали на морських свинках за методом В. А. Волковой (2010) [1]. Усіх експериментальних тварин утримували в стандартних умовах віварію Львівського національного медичного університету імені Данила Галицького. Евтаназію тварин проводили під ефірним наркозом шляхом декапітації з дотриманням Європейської конвенції про захист хребетних тварин, яких використовують для експериментальних та інших наукових цілей (Страсбург, 1985). Для оцінки інтенсивності ПОЛ були використані показники дієнових кон'югатів (ДК) за методом В. Г. Гаврилова, М. І. Мишкорудної (1989) [2], малонового діальдегіду (МДА) за методом Е. Н. Коробейникова (1989) [3]. Ступінь активності АОС

оцінювали за вмістом ферментів - супероксидисмутази (СОД) за методом R. Fried (1975) [13], каталази (КT) за методом R. Holmes, C. Masters (1970) [14], глутатіонпероксидази (ГПО) - за методом О. Г. Архиповой (1988) [16], глутатіонредуктази (ГР) - за методом В. М. Моїна [5]. Статистичне опрацювання одержаних даних здійснювали за методом Стьюдента.

Результати й обговорення. Результати експериментальних досліджень показали поступову інтенсифікацію процесів вільнорадикального окиснення в легенях у динаміці розвитку контактного дерматиту. Було зафіксовано підвищення вмісту дієнових кон'югатів у легенях на 4, 8, 10 і 18 доби КД відповідно на 12,6\% ( $\leq \leq 0,05), 29,3 \%$ ( $\leq \leq 0,05)$, $34,9 \%(p \leq 0,05)$ та 53,9\% ( $p \leq 0,001)$, порівняно 3 тваринами інтактної групи, що вказує на інтенсивне утворення продуктів ліпопероксидації (рис. 1).

Визначення іншого показника ПОЛ - малонового діальдегіду, в легенях морських свинок, дало можливість виявити аналогічний напрямок змін, подібних до ДК за умов формування КД. На 4, 8, 10 і 18 доби експерименту встановлено зростання вмісту МДА відповідно на $13,2 \%(p \leq 0,05)$, $25,5 \%, 65,2 \%$ і $64,3 \%(p \leq 0,05)$ вище від контрольної групи тварин.

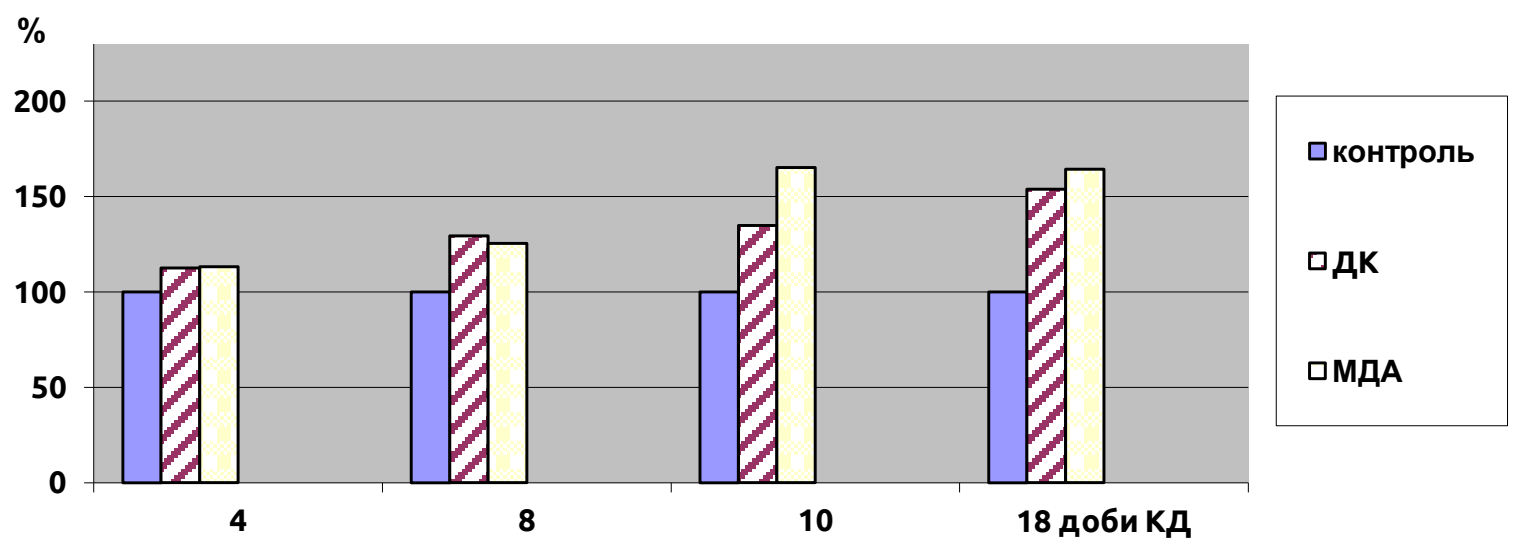

Рис. 1. Вміст продуктів ліпопероксидації в легенях морських свинок у динаміці формування КД (\% від контролю).

Надмірне утворення продуктів пол викликало порушення функціонування антиоксидантного захисту. Зокрема, дослідження активності супероксиддисмутази в ранні терміни експерименту показало їі зростання у легенях на $16,8 \%(p \leq 0,05)$ на 4 добу експерименту, порівняно з І групою тварин, що може свідчити про включення компенсаторних механізмів захисту. Проте, вже на 8 добу експериментального КД активність СОД знаходилась на рівні контрольних величин $(p \geq 0,05)$. Згодом ми встановили зниження ії активності на 10 і 18 доби на 21,9\% $(p \leq 0,05)$ і $36,8 \%(p \leq 0,05)$ щодо контролю (рис. 2).
Аналогічний вектор змін виявлений під час дослідження активності каталази в легенях. На 4 добу КД виявлене підвищення ії рівня на $24,9 \%$ $(p \leq 0,05)$ і зниження практично до вихідного рівня на 8 добу експерименту, порівняно з групою інтактних морських свинок ( $p \geq 0,05)$. На 10 і 18 доби цієї експериментальної моделі хвороби встановлено зниження активності цього ензиму відповідно на $23,6 \%(p \leq 0,05)$ і $39,1 \%(p \leq 0,05)$ проти контролю, що вказує на пригнічення антиоксидантного захисту в легенях за умов розвитку КД. 
Огляди літератури, оригінальні дослідження, погляд на проблему, випадок з практики, короткі повідомлення

Для більш повноцінної характеристики АOC проводили також дослідження активності ГПО та ГР. Ми встановили, що на 4 добу КД активність ГПО достовірно не змінювалася і була на рівні показників групи інтактних тварин ( $\geq \geq 0,05)$. Зате піз- ніше, на 8 добу, відбувалося її помірне зниження на $17,2 \%(p \leq 0,05)$, і ще вираженіший спад на 10 i 18 доби відповідно на 20,7 \% (p<0,05) і на 46,5 \% $(p \leq 0,05)$ проти першої групи морських свинок (рис. 2).

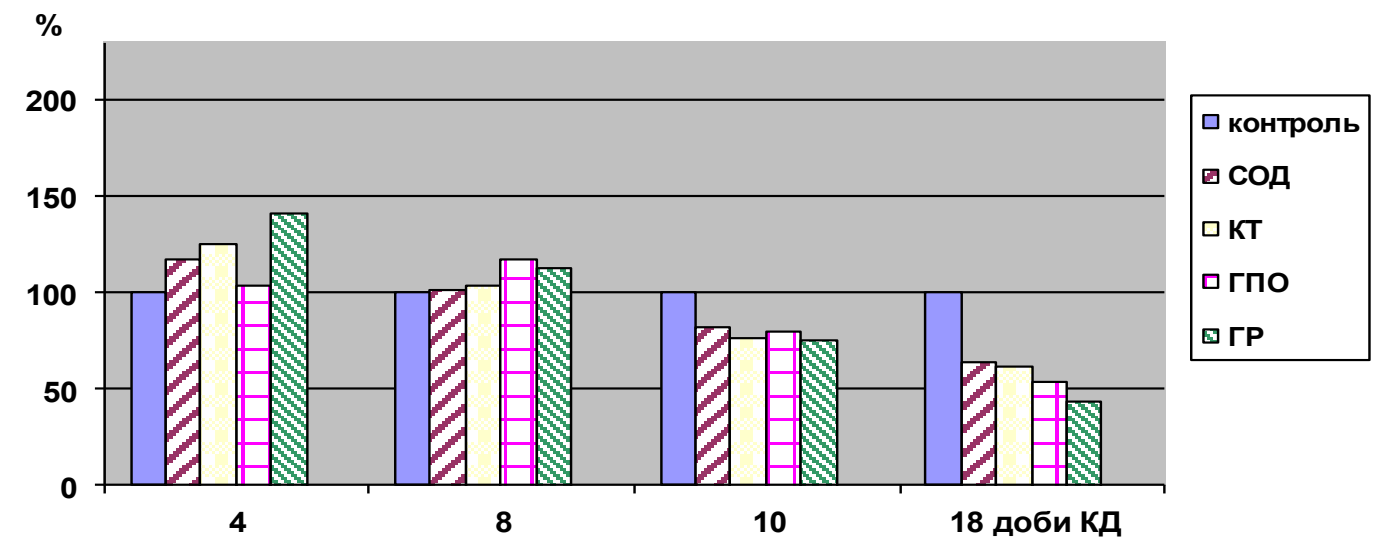

Рис. 2. Активність ферментів АОС у легенях морських свинок у динаміці формування КД (\% від контролю).

Важливим ферментом, який доповнює характеристику інших, $\epsilon$ глутатіонредуктаза. Вагоме зростання активності цього ферменту в леге-

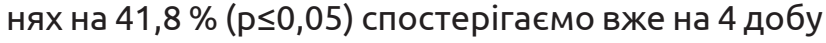
КД. 8 доба експерименту також характеризувалася збільшенням рівня цього маркера, але лише на $11,8 \%(p \leq 0,05)$ проти інтактної групи. Визначення даного ферменту в легенях у пізній період КД дозволило виявити наступне поступове зниження його активності, як на 10, так і на 18 доби, відповідно на 24,7 \% (ps0,05) і на 57,6 \% $(p \leq 0,05)$ проти контрольної групи.

Одержані дані дають підставу стверджувати про пригнічення ферментативної активності антирадикального захисту в легенях у пізній період розвитку контактного дерматиту.

Висновки. Проведений комплекс біохімічних досліджень показників вільнорадикального окис- нення і антиоксидантного захисту показав виражені зміни впродовж формування експериментального КД. Встановлено поступове зростання вмісту ДК і МДА при одночасному збільшенні активності ферментної ланки захисту лише в ранній період розвитку контактного дерматиту, а надалі активність ензимів різко знижувалась, що свідчило про домінування механізмів пошкодження над механізмами захисту, розвиток оксидантного стресу, що посилює запальний процес і сприяє формуванню різних ускладнень, утруднює терапію.

Перспективи подальших досліджень. У подальшому планується дослідження прооксидантної та антиоксидантної систем у шкірі морських свинок у динаміці розвитку експериментального контактного дерматиту при експериментальній пневмонії.

\section{ЛІТЕРАТУРА}

1. Волкова В. А. Вивчення лікувальної ефективності нової мазі з ліпофільним комплексом із кори осики "Тремулін" за умов неалергічного контактного дерматиту в щурів / В. А. Волкова, І. В. Кучинська, Т. І. Тюпка // Фармакологія та лікарська токсикологія. - 2010. № 6. - С. 7-12.

2. Гаврилов В. Б. Спектрофотометрическое определение содержания гидроперекисей липидов в плазме крови / В. Б. Гаврилов, М. И. Мишкорудная // Лабораторная диагностика ишемической болезни сердца. К. : Здоровье, 1989. - С. 170-171.

3. Коробейникова Э. Н. Модификация определения продуктов ПОЛ в реакции с тиобарбитуровой кислотой / Э. Н. Коробейникова // Лабораторное дело. 1989. - № 7. - C. 8-10.
4. Литвинець $€$. А. Перекисне окиснення ліпідів та антиоксидантний захист у разі патології сечовидільної системи, доцільність використання біофлавоноїдів у комплексному лікуванні / Є. А. Литвинець, Я. В. Гоцуляк // Здоровье мужчины. - 2012. - № 1. - С. 135-137.

5. Моин В. М. Простой и специфический метод определения активности глутатионпероксидазы в эритроцитах / В. М. Моин // Лабораторное дело. - 1986. № 12. - С. 724-727.

6. Определение активности пероксидазы в крови // Методы исследования в профпатологии / под ред. О. Г. Архиповой. - М. : Медицина, 1988. - С. 153.

7. Процеси ліпопероксидації та стан АО системи в міокарді щурів за умов інтоксикації антрацикліновими антибіотиками / І. В. Ніженковська, О. І. Ніженковський, 
Огляди літератури, оригінальні дослідження, погляд на проблему, випадок з практики, короткі повідомлення В. В. Вільчинська [та ін.] // Сучасні проблеми токсиколоriï. - 2012. - № 2. - C. 45-47.

8. Тяжка О. В. Стан перекисного окислення ліпідів та антиоксидантної системи у дітей різного віку / О. В. Тяжка, Я. М. Загородня // Перинатология и педиатрия. 2016. - № 2. - С. 101-105.

9. Худан-Цільо І. І. Структурні зміни шкіри при контактному нікелевому дерматиті / І. І. Худан-Цільо, М. М. Корда // Вісник морфології. - 2017. - № 2, Т. 23. - С. 198-202.

10. Allergic Contact Dermatitis / L. Kostner, F. Anzengruber, C. Guillod [et al.] // Immunol. Allergy Clin. North Am. - 2017. - No. 37 (1). - P. 141-152.

11. Proceedings of the Global IAD Expert Panel. Incontinence-Associated Dermatitis: Moving Prevention Forward. Available at: https://bit.ly/1UPrmaD (accessed 05.04.2018) / D. Beeckman, J. Campbell, D. Chimentao [et al.]. Wounds International, London, 2015. - 21 p.

12. Ji H. Oxidative stress in atopic dermatitis / H. Ji, X. K. Li // Oxidative medicine and cellular longevity. 2016. - No. 4. - P. 261-265.

\section{REFERENCES}

1. Volkova, V.A., Kuchynska, I.V., \& Tiupka T.I. (2010). Vyvchennia likuvalnoi efektyvnosti novoi mazi z lipofilnym kompleksom iz kory osyky "Tremulin" za umov nealerhichnoho kontaktnoho dermatytu v shchuriv [Study of the therapeutic efficacy of a new ointment with a lipophilic complex of the Tremulin aspen bark under conditions of non-allergic contact dermatitis in rats]. Farmakolohiya ta likarska toksykolohiia - Pharmacology and Drug Toxicology, 6, 7-12 [in Ukrainian].

2. Gavrilov, V.B., \& Mishkorudnaya, M.I. (1989). Spektrofotometrycheskoe opredelenye soderzhaniya gidroperekysey lipidov v plazme krovi. Laboratornaya diagnostika ishemicheskoy bolezni serdtsa. [Spectrophotometric determination of lipid hydroperoxides in blood plasma. Laboratornaya diagnostika ishemicheskoy bolezni serdtsa]. Kyiv: Zdorovye, 170-171 [in Russian].

3. Korobeynikova, E.N. (1989). Modifikatsiya opredeleniya produktov POL $v$ reaktsii s tiobarbiturovoy kislotoy [Modifikation of determination of LP products in reaction with thiobarbituric acid]. Laboratornoye delo - Laboratory Case, 7, 8-10 [in Russian].

4. Lytvynets, E.A., \& Hotsuliak, Ya.V. (2012). Perekysne okysnennia lipidiv ta antyoksydantnyi zakhyst u razi patolohii sechovydilnoi systemy, dotsilnist vykorystannia bioflavonoidiv u kompleksnomu likuvanni [Lipid peroxidation and antioxidant protection in case of pathology of the urinary system, expediency of using bioflavonoids in complex treatment]. Zdorovye muzhchiny - Health of a Man, 1, 135137 [in Ukrainian].

5. Moin, V.M. (1986). Prostoy i spetsyficheskyy metod opredeleniya aktivnosti glutatyonperoksydazy v erytrotsytakh [Simple and specific method of determination of activity of glutathion reductase in erythrocytes]. Laboratornoe delo - Laboratory Case, 12, 724-727 [in Russian].

6. Arkhipova, O.H. (1988). Opredelenie aktivnosti peroksidazy v krovi. Metody issledovaniya v profpatologii [Determination of peroxidase activity in blood. Methods of re-

13. Fried R. Enzymatic and non-enzymaticassay of superoxide ifilii / R. Fried // Biochemie. - 1975. - Vol. 57, No. 5. - P. 657-660.

14. Holmes R. Epigenetic interconversions of the multiple forms of mouse liver catalase / R. Holmes // FEBS Lett. - 1970. - Vol. 11, No. 1. - P. 45-48.

15. Kubesy A. A. Altered blood oxidative stress biomarkers in association with canine pyoderma and allergic contact dermatitis / A. A. Kubesy, N. Y. Salem, A. H. Jaheen // Comparative Clinical Pathology. - 2017. Vol. 26 (3). - P. 643-646.

16. Nimse S. B. Free radicals, natural antioxidants, and their reaction mechanisms / S. B. Nimse, D. Pal // Rsc. Advances. - 2015. - Vol. 5, No. 35. - P. 27986-28006.

17. Pisoschi A. M. The role of antioxidants in the chemistry of oxidative stress: A review / A. M. Pisoschi, A. Pop // European Journal of Medicinal Chemistry. 2015. - Vol. 97. - P. 55-74.

search in professional pathology]. Moscow: Meditsina [in Russian].

7. Nizhenkovska, I.V., Nizhenkovskiy, O.I., Vilchynska, V.V., Filipova, K.Yu., \& Chumak, N.Ye. (2012). Protsesy lipoperoksydatsii ta stan AO systemy $v$ miokardi shchuriv za umov intoksykatsii antratsyklinovymy antybiotykamy [Processes of lipoperoxidation and state of AO systems in myocardium of rats under condition of intoxication of antracylic antibiotics]. Suchasni problemy toksykolohii - Modern Problems of Toxicology, 2, 45-47 [in Ukrainian].

8. Tiashka, O.V., \& Zahorodnia, Ya.M. (2016). Stan perekysnoho okyslennia lipidiv ta antyoksydantnoi systemy u ditei riznoho viku [State of lipid peroxidation and antioxidant system in children of all ages]. Perynatolohiia $i$ pediatriia - Perynatologia and Pediatrics, 2, 101-105 [in Ukrainian].

9. Chudan-Tsilo, I.I., \& Korda, M.M. (2017). Strukturni zminy shkiry pry kontaktnomu nikelevomu dermatyti [Structural changes of the skin in contact nickel dermatitis]. Visnyk morfolohii - Bulletin of Morphology, 2, 23, 198202 [in Ukrainian].

10. Kostner, L., Anzengruber, F., Guillod, C., Recher, M., Schmid-Grendelmeier, P., \& Navarini, A.A. (2017). Allergic contact dermatitis. Immunology and Allergy Clinics, 37 (1), 141-152.

11. Beeckman, D., Campbell, J., Chimentro, D., Chimentao, D., Coyer, F., Domansky, R., ..., \& Wang, L. (2015). Proceedings of the Global IAD Expert Panel. Incontinence-Associated Dermatitis: Moving Prevention Forward. Wounds International, London. Retrievtd from: https://bit.ly/1UPrmaD

12. Ji, H., \& Li, X.K. (2016). Oxidative stress in atopic dermatitis. Oxidative Medicine and Cellular Longevity.

13. Fried, R. (1975). Enzymatic and nonenzymatic assay of superoxide ifilli. Biochemie, 57 (5), 657-660.

14. Holmes, R., \& Masters, C.J. (1970). Masters with epigenetic interconversions of the multiple forms of mouse liver catalase. FEBS Lett, 11 (1), 45-48. 
Огляди літератури, оригінальні дослідження, погляд на проблему, випадок з практики, короткі повідомлення

15. Kubesy, A.A., Salem, N.Y., \& Jaheen, A.H. (2017). Altered blood oxidative stress biomarkers in association with canine pyoderma and allergic contact dermatitis. Comparative Clinical Pathology, 26 (3), 643-646.

16. Nimse, S.B., \& Pal, D. (2015). Free radicals, natural

antioxidants, and their reaction mechanisms. Rsc. Advances., 5, 35, 27986-28006.

17. Pisoschi, A.M., \& Pop, A. (2015). The role of antioxidants in the chemistry of oxidative stress: A review. European Journal of Medicinal Chemistry, 97, 55-74.

\section{ДИНАМИКА ИЗМЕНЕНИЙ ПРОЦЕССОВ ЛИПОПЕРОКСИДАЦИИ И АНТИОКСИДАНТНОЙ СИСТЕМЫ В ЛЕГКИХ В ПАТОГЕНЕЗЕ РАЗВИТИЯ ЭКСПЕРИМЕНТАЛЬНОГО КОНТАКТНОГО ДЕРМАТИТА}

ФМ. М. Регеда-Фурдичко

\section{Львовский медицинский институт}

РЕЗЮМЕ. Цель работы - изучить особенности состояния прооксидантной и антиоксидантной систем в легких морских свинок в динамике развития экспериментального контактного дерматита.

Материал и методы. Исследования проводили на морских свинках, поделенных на пять групп: I группа контрольная, II - 4 сутки эксперимента, III - 8 сутки развития контактного дерматита, IV - 10 сутки и V - 18 сутки моделируемого процесса. Ранний период включал группу животных на 4 и 8 сутки эксперимента. Поздний - морские свинки на 10 и 18 сутки контактного дерматита. Экспериментальная модель контактного дерматита воспроизводилась методом В. А. Волкова (2010). Состояние свободнорадикального окисления липидов в легких определяли по содержанию диеновых конъюгатов методом В. Г. Гаврилова, М. И. Мышкорудной (1989), и малонового диальдегида методом Е. Н. Коробейникова (1989). Степень активности антиоксидантной защиты оценивали по содержанию ферментов супероксиддисмутазы методом R. Fried (1975), каталазы методом B. Holmes, C. Masters (1970), глутатионредуктазы методом В. М. Моина (1986) и глутатионпероксидазы методом О. Г. Архиповой (1988).

Результаты и обсуждение. В работе установлен постепенный интенсивный рост продуктов перекисного окисления липидов - диеновых конъюгатов и малонового диальдегида, особенно выраженное на 18 сутки эксперимента. Выявлено снижение активности супероксиддисмутазы, каталазы, глутатионредуктазы и глутатионпероксидазы в легких морских свинок в позднем периоде экспериментального контактного дерматита. Полученные результаты свидетельствуют о нарушении баланса прооксидантной и антиоксидантной систем, которое проявляется усилением синтеза свободных радикалов на фоне угнетения компенсаторных реакций.

КЛючЕВЫЕ СЛОВА: контактный дерматит; малоновый диальдегид; диеновые конъюгаты; супероксиддисмутаза; каталаза; глутатионпероксидаза; глутатионредуктаза.

\section{DYNAMICS OF CHANGES IN THE PROCESSES OF LIPOPEROXIDATION AND ANTIOXIDANT SYSTEM IN LUNGS IN THE PATHOGENESIS OF EXPERIMENTAL CONTACT DERMATITIS}

\section{Lviv Medical Institute}

@M. M. Regeda-Furdychko

SUMMARY. The aim of the work - to study the features of the conditions of prooxidant and antioxidant system in the lungs of guinea pigs in the development of contact dermatitis.

Materials and Methods. Researches were conducted on guinea pigs, divided into five groups: I - control, II - 4th day of experiment, III - 8th day of contact dermatitis development, IV - 10th day and V - 18th day of model process. Early period included groups of animals on the 4th and 8th days of experiment. The late one - guinea pigs on the 10 th and 18 th days of contact dermatitis. Experimental contact dermatitis was simulated by method of V. A. Volkova (2010). Condition of free radical lipid oxidization in the lungs was determined on maintenance content of malonic dialdehyde by method of E. H. Korobeinikov (1989) and diene conjugates by method of V. H. Havrylov, M. I. Myshkorudna (1989). The degree of activity of antioxidant defence was estimated on maintenance enzymes - superoxidedismutase by method of R. Fried (1975), catalase by the method of B. Holmes, C. Masters (1970), glutationperoxidase method of O. G. Arkhipova (1988) and glutationreductase method of V. M. Moina (1986).

Results and Discussion. Gradual intensive increasing of lipid peroxidation products - malonic dialdehyde, diene conjugate had been determined in this research, especially expressed on the 18 th day of experiment. Decreasing of the indices of superoxidedismutase, glutationreductase, glutationperoxidase and catalase was investigated in the lungs of guinea pigs in the late period of formation of experimental contact dermatitis. The got results testify about imbalance in antioxidant and prooxidant systems in pathogenesis of contact dermatitis development. It shows up increasing of free radicals synthesis on the background of exhaustion of compensatory reactions.

KEY WORDS: contact dermatitis; malonic dialdehyde; diene conjugate; superoxidedismutase; catalase; glutationperoxidase; glutationreductase. 